\title{
Effect of the big flood events on the water quality of the Muar River, Malaysia
}

\author{
Yun Chen Ching ${ }^{1}$ (D) Yook Heng Lee ${ }^{1} \cdot$ Mohd Ekhwan Toriman ${ }^{2,3} \cdot$ \\ Maimon Abdullah ${ }^{1} \cdot$ Baharudin Bin Yatim $^{1}$
}

Received: 8 May 2015/Accepted: 22 May 2015/Published online: 3 June 2015

(c) Springer International Publishing 2015

\begin{abstract}
This study is carried out in order to examine the impacts of flood events on water quality status of Muar River. The water samples consisting of six water quality parameters, namely dissolved oxygen, biochemical oxygen demand, chemical oxygen demand, ammoniacal-nitrogen, $\mathrm{pH}$ value, and total suspended solids were used to compute the water quality index (WQI) at Muar River. Mean annually and monthly water quality variations of the nine sampling stations along Muar River over 2 years period (2006-2007) were investigated together with the monthly and annual rainfall pattern of the 22 rainfall stations within the basin. The relationship between monthly rainfall and water quality of Muar River for the period before and after the flood events was analyzed using Pearson correlation coefficient. In December 2006 and January 2007, the total monthly rainfall recorded was over 145 and $70 \%$, respectively, of the total monthly average rainfall of 31 years (from 1980 to 2010). The 2006/2007 Malaysian big flood events in December 2006 and January 2007 have resulted in lowest monthly WQI of 56.4 in Polluted category and within Class III in January 2007; while December 2006 and February 2007 flood events were categorized as Slightly Polluted and placed in Class III. Rainfall had higher
\end{abstract}

Yun Chen Ching

cycyunchen@yahoo.com

1 Faculty of Science and Technology, National University of Malaysia, UKM, 43600 Bangi, Selangor, Malaysia

2 Faculty of Social Sciences and Humanities, National University of Malaysia, UKM, 43600 Bangi, Selangor, Malaysia

3 East Coast Environmental Research Institute, Universiti Sultan Zainal Abidin, (UniSZA), Kuala Terengganu, Terengganu, Malaysia correlation strengths with WQI and water quality parameters in the period before and during the first wave of flood events. Results of this study could be useful in supporting management decisions in mitigating the adverse effects of flood on the surface water resources.

Keywords Flood events - Muar River · Water quality parameters · Water quality index (WQI) - Rainfall

\section{Introduction}

Flooding results from excessive rain on the land, or when a river or stream overflows its natural or artificial banks, flooding the surrounding floodplain. There are many different types of flooding but the most common are river floods, flash floods, coastal floods, and urban floods. Floods are recurring phenomena that can happen either slowly, through long periods of rainfall, or else, very quickly through sudden events like rainstorms. Although floods are natural phenomena, human activities could intervene with the natural process, e.g., alterations in the drainage patterns due to urbanization, agricultural practices, and deforestation, thus, considerably altering the river basins and resulting in larger sediment yields from water catchments (UNESCO 2011). Climate change processes could intensify the hydrological cycle, leading to abnormal frequencies in the occurrence and intensity of climatologic events. This could be manifested by more intense and temporally variable precipitation, greater occurrence and intensity of floods and droughts, more severe tropical storms, and increased wildfires (Sehmi 2009).

Major floods could incur great economic losses, particularly in densely populated urban areas and in more developed countries. Floods are in fact, the most damaging 
phenomena of all natural risks, affecting the socio-economic aspects of the population worldwide. The negative impacts of flooding include spread of communicable diseases; destruction of natural habitats, crops, livestock, homes, and properties; degradation in the water quality; and loss of natural vegetation and animals. Flooding puts life and property at risk as well as causing surface water pollution by overloading both the natural rivers and the artificial drainage.

Climate and rainfall are closely interrelated. Increasing rainfall variability and extremes as a consequence of climate change can influence surface water quality because the rainwater picks up surface materials, soils, wastes and other pollutants in runoff from slopes, open grounds, lawns, farms, streets, factories, and other areas into the receiving water bodies. Contamination of large water bodies is often much higher during and immediately after rainstorms (Water Research Foundation 2008), the increase in precipitation intensity is expected to lead to a deterioration of water quality, as it results in the inputs of pollutants particularly excessive nutrients, organic material, hazardous substances, pathogens, and other dissolved pollutants (e.g., pesticides); and in increased erosion, which in turn leads to the mobilization of adsorbed pollutants such as phosphorus and heavy metals into the surface waters and groundwater. Water pollution is a serious global problem that impacts the health of freshwater system, food production, and health care (Credit Valley Conservation 2009).

Malaysia, being located near the equator, receives full daily sunshine, with high relative humidity (ranging from 56 to $97 \%$ ), and high temperature (average of $27^{\circ} \mathrm{C}$ or $80.6^{\circ} \mathrm{F}$ ) almost all the year round. The rainfall distribution in Malaysia is largely determined by intense convective precipitation with the coastal areas facing the South China Sea, and is highly influenced by the Northeast Monsoons (November-March) and Southwest Monsoons (MaySeptember). The average annual rainfall is $2400 \mathrm{~mm}$ for Peninsular Malaysia, $3800 \mathrm{~mm}$ for Sarawak, and $2600 \mathrm{~mm}$ for Sabah. Malaysia experienced annual northeast monsoonal floods that vary in terms of severity and location. The northeast monsoon also brings heavy rainfall, which could persist for days on end. There are two transitional periods in between the two monsoons known as the intermonsoon (April-May, October-November) when convectional thunderstorms are common (MMD 2010).

Trends in extreme precipitation events are receiving global attention due to global warming and climate change. In the periods of 17-20 December 2006, 24-28 December 2006, and 10-14 January 2007, Peninsular Malaysia was hit by a series of continual and abnormally heavy rainfall and storm events generated by the unusual Northeast Monsoon coming from the South China Sea and the West Pacific Ocean, and causing severe floods in the southern
Peninsular states of Negeri Sembilan, Melaka, Pahang, and Johor. Abnormally high daily rainfalls of $200-300 \mathrm{~mm}$ were recorded in some of the rainfall stations in the Districts of Muar and Segamat, which had exceeded the longterm mean monthly rainfall for the region. The worst affected areas were along the major rivers such as the Johor River, the Batu Pahat River, the Segamat River, and the Muar River (DID Johor 2007). After the big flood events in December 2006 and January 2007, a smaller flood event had occurred in December 2007, with average total monthly rainfall of $368.84 \mathrm{~mm}$.

\section{Characteristics of the study area}

The Muar River is the main artery of the Muar River Basin, flowing through the states of Negeri Sembilan, Pahang, and Johor in the south Peninsular Malaysia with the total length of $329 \mathrm{~km}$. The origin of the river is a site called Jambu Lapan in Jempol, Negeri Sembilan, from which the upstream parts of the Muar River cover the central areas, Kuala Pilah of Negeri Sembilan, and the river then flows to the southeast region until Kampung Awat, then turns southwards at Bukit Kepong. The downstream part covers most of the Muar district in Johor, where the river flows southwest through the urban areas of Muar town, and finally entering the Malacca Straits at Kuala Muar, in Johor.

A river basin is the area of land from which all surface runoff flows through a sequence of streams, rivers and, possibly, lakes into the sea at a single river mouth, estuary or delta. The Muar River Basin, which lies from latitude $1^{\circ} 52^{\prime} 00^{\prime \prime}$ North to $2^{\circ} 54^{\prime} 00^{\prime \prime}$ North and from longitude $102^{\circ} 14^{\prime} 00^{\prime \prime}$ East to $103^{\circ} 04^{\prime} 00^{\prime \prime}$ East, is a state transboundary river basin shared between the states of Negeri Sembilan, Johor, Melaka, and Pahang. The river basin covers an area of $6138 \mathrm{~km}^{2}$, of which, $3601 \mathrm{~km}^{2}(58.7 \%)$ is located in Johor, while the rest $(39.2 \%)$ is in Negeri Sembilan, and small portions are located in Pahang $(1.98 \%)$ and in Melaka $(0.13 \%)$, respectively.

The major land use within the Muar River Basin is under natural forests, open grounds, swamps, scrub, and secondary growths, while the rest comprise oil palm and rubber plantations, agriculture, settlement areas, and other land uses. The densely populated areas are in the urban townships of Muar, Segamat, Labis, Gemas, and Kuala Pilah (DOA Malaysia 2006). The rapid rise in human population and urbanization in recent years have resulted in the gradual deterioration of the water quality of the Muar River, particularly due to discharges of industrial wastewater and agricultural runoff.

The Muar River is one of the large and important rivers in Malaysia, with significant influence over the socio- 
economic status of the surrounding communities. It is the main source of livelihood, water and protein supply (fishery resources), and the major mode of transportation for the community, for trade and commerce. In the modern times, the Muar River still has very much to offer to its communities, especially in terms of agriculture, aquaculture, and recreational activities (leisure fishing, boating, etc.), and it is still the sole source of drinking water for the entire Muar District, a large section of the Ledang District and a reserved water reservoir for the Melaka state.

\section{Materials and methods}

For the purpose of this study, a 2-year water quality data from January 2006 to November 2007 were acquired from the Department of Irrigation and Drainage (DID) Malaysia and Department of Environment (DOE) Malaysia for the nine water quality monitoring stations located along the Muar River. For each site, a total of six water quality variables, i.e., Dissolved oxygen (DO), Biochemical oxygen demand (BOD), Chemical oxygen demand (COD), $\mathrm{pH}$ value $(\mathrm{pH})$, ammoniacal-nitrogen $\left(\mathrm{AN} / \mathrm{NH}_{3}-\mathrm{N}\right)$, and total suspended solids (TSS) were analyzed to derive the water quality index (WQI) of the Muar River.

WQI has been developed to assess the suitability of water for a variety of uses. Different pollutants and factors are required for the development of an index. Most of the WQI development in many countries requires selection of water quality parameters and assigning optional weights of the selected parameters. WQI combines a group of important water quality parameters that give an overall index of the water quality for a specific use (Davis and McCuen 2005).

The WQI approved by the DOE Malaysia is an opinionpoll formula, the determining processes were based on personal evaluation, namely, opinion-gathering and questionnaire survey techniques used to develop WQI where selected influential variables were identified with respective weights. The WQI was used as a basis for assessment of a watercourse in relation to pollution load categorization and comprises weighted linear aggregation of sub-indices of DO, BOD, COD, AN, SS, and $\mathrm{pH}$. These parameters were selected by the panel of experts as being the parameters that will give some indication on the water quality level or WQI of a river (DOE Malaysia 1994) when calculated and used collectively. The concentration of each parameter in the water body may have different effects on human health and aquatic species, this concentration is a measurable value and the value of effects it carries is unitless that needs to be quantified. This unitless value is the sub-index value and is obtained from sub-index structure, which is the basic structure that relates to the effect of concentration for a specific parameter.

In order to obtain a sub-index value from each parameter, each panelist drew a curve which they felt best represented the variation in water quality produced by the various levels of each parameter; levels of water quality range from 0 to 100 were indicated on the $y$-axis of each graph while increasing levels of the particular parameter were indicated on the $x$-axis. Then, all the curves had been averaged to produce a single line for each parameter, so that the sub-index value for the concentration of each parameter can readily be obtained on a common scale from 0 to 100 , higher value of the index indicates better quality of water. Each sub-index will be aggregated with other subindices to give a final WQI value. Thus, each rating curve needs to be transformed into mathematical equations to aggregate it appropriately. Statistical analysis of the ratings was used to assign weights to each parameter, where the sum of the weights is equal to 1 . In water quality, weight denotes the relative importance of each water quality parameter and is used to consider differences in the importance of parameter. Weight is also defined as relative weight or importance weighting factor (Dunnette 1979), weighting factor (Inhaber 1975), and perceived importance (Smith 1990). The weights for each variable indicate the relative importance of the variables in determining WQI in Malaysia. Among them DO carries maximum weightage of 0.22 and $\mathrm{pH}$ carries the minimum of 0.12 in the WQI equation.

The WQI is a unitless number and calculated from the Eq. 1 as given below, the sub-index value multiplied with the weighing factor to get the weighted value of sub-index for calculating the WQI.

$$
\begin{aligned}
\mathrm{WQI}= & (0.22 * \mathrm{SIDO})+(0.19 * \mathrm{SIBOD}) \\
& +(0.16 * \mathrm{SICOD})+(0.15 * \mathrm{SIAN}) \\
& +(0.16 * \mathrm{SISS})+(0.12 * \mathrm{SIpH}),
\end{aligned}
$$

where SI refers to the sub-index function for each of the given parameters, SIDO $=$ Sub-index of DO, SIBOD = Sub-index of BOD, SICOD $=$ Sub-index of COD, SIAN $=$ Sub-index of $\mathrm{NH}_{3}-\mathrm{N}$, SISS $=$ Sub-index of SS, SIpH $=$ Sub-index of $\mathrm{pH}$.

Sub-indexes values are calculated according to the best fit equations given in Eqs. 2-7. Sub-index for DO (in \% saturation):

$$
\begin{aligned}
& \text { SIDO }=0 \text { for } x \leq 8 \\
& \text { SIDO }=100 \text { for } x \geq 92 \\
& \text { SIDO }=-0.395+0.030 x^{2}-0.00020 x^{3} \text { for } 8<x<92
\end{aligned}
$$


Sub-index for BOD:

SIBOD $=100.4-4.23 x$ for $x \leq 5$

$\mathrm{SIBOD}=108 * \exp (-0.055 x)-0.1 x$ for $x>5$

Sub-index for COD:

$\mathrm{SICOD}=-1.33 x+99.1$ for $x \leq 20$

SICOD $=103 * \exp (-0.0157 x)-0.04 x$ for $x>20$

Sub-index for $\mathrm{AN} / \mathrm{NH}_{3}-\mathrm{N}$ :

SIAN $=100.5-105 x$ for $x \leq 0.3$

$\mathrm{SIAN}=94 * \exp (-0.573 x)-5 *|x-2|$ for $0.3<x<4$

$\mathrm{SIAN}=0 \quad$ for $x \geq 4$

Sub-index for SS:

$$
\begin{aligned}
& \text { SISS }=97.5 * \exp (-0.00676 x)+0.05 x \text { for } x \leq 100 \quad \text { (6a) } \\
& \text { SISS }=71 * \exp (-0.0061 x)-0.015 x \quad \text { for } 100<x<1000
\end{aligned}
$$

SISS $=0$ for $x \geq 1000$

Sub-index for $\mathrm{pH}$ :

$$
\begin{aligned}
& \text { SIpH }=17.2-17.2 x+5.02 x^{2} \quad \text { for } x<5.5 \\
& \text { SIpH }=-242+95.5 x-6.67 x^{2} \quad \text { for } 5.5 \leq x<7 \\
& \text { SIpH }=-181+82.4 x-6.05 x^{2} \quad \text { for } 7 \leq x<8.75 \\
& \text { SIpH }=536-77.0 x+2.76 x^{2} \quad \text { for } x \geq 8.75
\end{aligned}
$$

The calculated WQI should fall within the range of $0 \leq \mathrm{WQI} \leq 100$, a higher index value represents better water quality. 100 is the highest possible score and denotes a pristine river and zero is the lowest. The WQI score can then be used to categorize a particular water body into one of five classes as provided for under the National Water Quality Standards for Malaysia (NWQS) (Table 1).

The WQI for rating the water quality in terms of a number has been used to indicate the degree of water pollution status (Table 2) and designation of classes of beneficial uses (Table 3), which makes it easily understandable for communities in the river basin and for river basin management. The WQI is widely used to evaluate the overall water quality of the rivers and as a tool in water quality classification according to the NWQS. By computing the WQI, the DOE, DID, and other relevant authorities could determine the cleanliness and availability of river water for domestic water supply, aquatic life, livestock drinking, recreational, and agricultural use (DOE Malaysia 1985). The water quality is considered to be suitable for a specific use as long as it is within the range specified for the designated class.

The historic weather data from January 1980 to December 2010 of the 22 rainfall stations in the Muar River Basin area, covering 31 years, were obtained from the DID Malaysia and the Malaysian Meteorological Department (MMD). The rainfall data of the 31 years, which included the $2006 / 2007$ big flood events were used to analyze the mean monthly and annual rainfall patterns from 1980 to 2010 in the Muar River Basin area. Figure 1 shows the base map of the Muar River Basin that has been prepared from the topographic maps of Kuala Pilah (JUPEM 1997), Bahau (JUPEM 1995), Gemencheh (JUPEM 1996), Segamat (JUPEM 1995), Gerisek (JUPEM 1997), Muar (JUPEM 2006), Bakri (JUPEM 2007) with the identified 22 rainfall stations in the area of Muar River Basin and the nine water quality stations along the Muar River.

In this study, the annual and monthly WQI of the Muar River in the period before, during, and after the 2006/07 big flood events was analyzed against the annual and monthly rainfall patterns of the Muar River Basin from January 2006 to December 2007. To investigate the effects of high rainfall and floods on the water quality of the Muar River, Pearson correlation coefficient $(r)$ test was performed. Correlation coefficient between the rainfall volume with the sub-index for each of the water quality parameters in WQI formula and the WQI value; and the correlation among the sub-index for all of the six water quality pa-

\begin{tabular}{|c|c|c|c|c|c|c|}
\hline \multirow[t]{2}{*}{ Parameter } & \multirow[t]{2}{*}{ UNIT } & \multicolumn{5}{|c|}{ CLASS } \\
\hline & & $\mathrm{I}$ & II & III & IV & $\mathrm{V}$ \\
\hline Ammoniacal-nitrogen $\left(\mathrm{NH}_{3}-\mathrm{N}\right)$ & $\mathrm{mg} / \mathrm{l}$ & $<0.1$ & $0.1-0.3$ & $0.3-0.9$ & $0.9-2.7$ & $>2.7$ \\
\hline Biochemical oxygen demand (BOD) & $\mathrm{mg} / \mathrm{l}$ & $<1$ & $1-3$ & $3-6$ & $6-12$ & $>12$ \\
\hline Chemical oxygen demand (COD) & $\mathrm{mg} / \mathrm{l}$ & $<10$ & $10-25$ & $25-50$ & $50-100$ & $>100$ \\
\hline Dissolved oxygen (DO) & $\mathrm{mg} / \mathrm{l}$ & $>7$ & $5-7$ & $3-5$ & $1-3$ & $<1$ \\
\hline $\mathrm{pH}$ & - & $>7.0$ & $6.0-7.0$ & $5.0-6.0$ & $<5.0$ & $>5.0$ \\
\hline Total suspended solid (TSS) & $\mathrm{mg} / \mathrm{l}$ & $<25$ & $25-50$ & $50-150$ & $150-300$ & $>300$ \\
\hline Water quality index (WQI) & & $>92.7$ & $76.5-92.7$ & $51.9-76.5$ & $31.0-51.9$ & $<31.0$ \\
\hline
\end{tabular}
rameters and the WQI value were calculated for the period before the flood events (from January 2006 until the month
Table 1 Class based-DOE water quality index classification
Source: Department of Environment Malaysia 
Table 2 Pollution status based-DOE water quality classification based on water quality index

\begin{tabular}{|c|c|c|c|}
\hline \multirow[t]{2}{*}{ Sub-index \& water quality index } & \multicolumn{3}{|c|}{ Index range } \\
\hline & Clean & Slightly polluted & Polluted \\
\hline Biochemical oxygen demand (BOD) & $91-100$ & $80-90$ & $0-79$ \\
\hline Ammoniacal-nitrogen $\left(\mathrm{NH}_{3}-\mathrm{N}\right)$ & $92-100$ & $71-91$ & $0-70$ \\
\hline Suspended solids (SS) & $76-100$ & $70-75$ & $0-69$ \\
\hline Water quality index (WQI) & $81-100$ & $60-80$ & $0-59$ \\
\hline
\end{tabular}

Source: Department of Environment Malaysia

Table 3 Water Quality Classes and Uses (National Water Quality Standards for Malaysia)

\begin{tabular}{|c|c|c|}
\hline Class & WQI & USES (Description of Classes) \\
\hline Class I & $>92.7$ & $\begin{array}{l}\text { Conservation of natural environment. Water Supply I-Practically no treatment } \\
\text { is necessary (except by disinfection or boiling only) } \\
\text { Fishery I-Very sensitive aquatic species }\end{array}$ \\
\hline Class IIA & $76.5-92.7$ & $\begin{array}{l}\text { Water supply II-Conventional treatment required } \\
\text { Fishery II-Sensitive aquatic species }\end{array}$ \\
\hline Class IIB & & Recreational use with body contact \\
\hline Class III & $51.9-76.5$ & $\begin{array}{l}\text { Water supply III-Extensive treatment required } \\
\text { Fishery III-Common, of economic value and tolerant species; livestock drinking }\end{array}$ \\
\hline Class IV & $31.0-51.9$ & Irrigation (not cover minor applications to sensitive crops) \\
\hline Class V & $<31.0$ & None of the above (represents other water, which does not meet any of the above uses) \\
\hline
\end{tabular}

Source: Department of Environment Malaysia

of first wave flood events, December 2006) and the period after the flood events (from the month of second wave flood events, January 2007 and the months after the flood events until November 2007) to determine if the relationships differed between before and after the 2006/07 big flood events. Statistical significance was tested at the alpha level of $0.05,0.02$, and 0.01 with 95,98 , and $99 \%$ confidence level, respectively.

\section{Results and discussion}

\section{Rainfall pattern}

The characteristic features of the rainfall pattern in the Muar River Basin were analyzed based on a 31-year period data (1980-2010) recorded at the 22 rainfall stations. The mean monthly rainfall and mean monthly rain days ( $\geq 0.1 \mathrm{~mm}$ of rainfall per day) of the 22 rainfall stations in the area for the year 1980-2010 are shown in Fig. 2. The analyzed results showed that the Muar River Basin had an average annual rainfall of $1707 \pm 250 \mathrm{~mm}$, and the average monthly rainfall of $146 \pm 31 \mathrm{~mm}$. The mean annual rain days and the mean monthly rain days in the area were $118.4 \pm 12.4$ and $9.34 \pm 1.72$ days, respectively. From 1980 to 2010 , the maximum rainfall was recorded in November and December, during the Northeast Monsoon. The highest average total monthly rainfall of
$198.1 \mathrm{~mm}$ was recorded in November, and followed by $187.5 \mathrm{~mm}$ in December. November was the month with the highest average monthly heavy rain days $(50<X<100 \mathrm{~mm} /$ day $)$ of $14 \mathrm{~h}$, the highest average monthly moderate rain days $(10<X \leq 50 \mathrm{~mm} /$ day $)$ of five days, and the highest average monthly light rain days ( $\leq 10 \mathrm{~mm} /$ day) of 6 days $15 \mathrm{~h}$, while December was the month with the highest average monthly with very heavy rain days $(\geq 100 \mathrm{~mm} /$ day $)$ of $5 \mathrm{~h}$. The lowest mean monthly rainfall of $90.1 \mathrm{~mm}$ was in February, and the second lowest mean monthly rainfall of $107.3 \mathrm{~mm}$ was in June.

\section{Rainfall and water quality index (WQI)}

Figure 3 gives the monthly rainfall pattern of the 22 rainfall stations in the Muar River Basin for 2006 and 2007, and the change in the WQI from January 2006 to November 2007 for nine sampling stations of the Muar River. The average total annual rainfall in 2006 was $2090.8 \mathrm{~mm}$ and for 2007, was $2150.5 \mathrm{~mm}$, which ranged as the second and third highest annual rainfall for the period from 1980 to 2010. According to the NWQS, the WQI values of the Muar River for year 2006 and 2007 were classified under Class II, where a higher WQI value of 83.2 was recorded in 2006, with the index range of clean, while a WQI value of 78.1 was recorded in 2007, with the index range of Slightly Polluted (Table 4). 
Fig. 1 Location of the 22 rainfall stations (R1-R22) and nine water quality stations (WQ1-WQ9) in the Muar River Basin

Fig. 2 Average total monthly rainfall and average total monthly rain days $(\geq 0.1 \mathrm{~mm}$ rainfall/day) of the 22 rainfall stations in the Muar River Basin area for the year 1980-2010
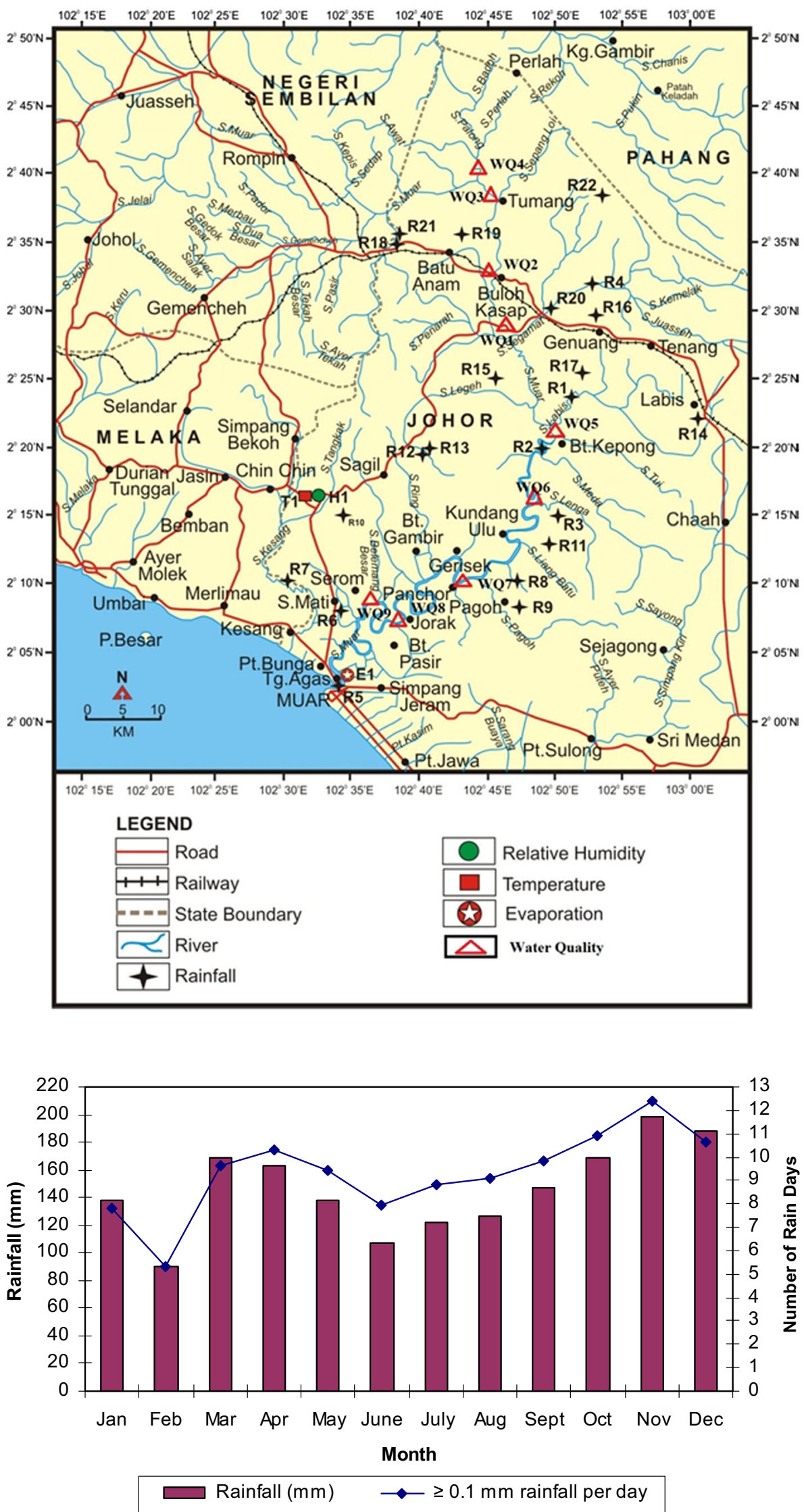
Fig. 3 Monthly water quality index for the average nine sampling stations of Muar River and average total monthly rainfall for the year 2006 and 2007 of the 22 rainfall stations in the Muar River Basin

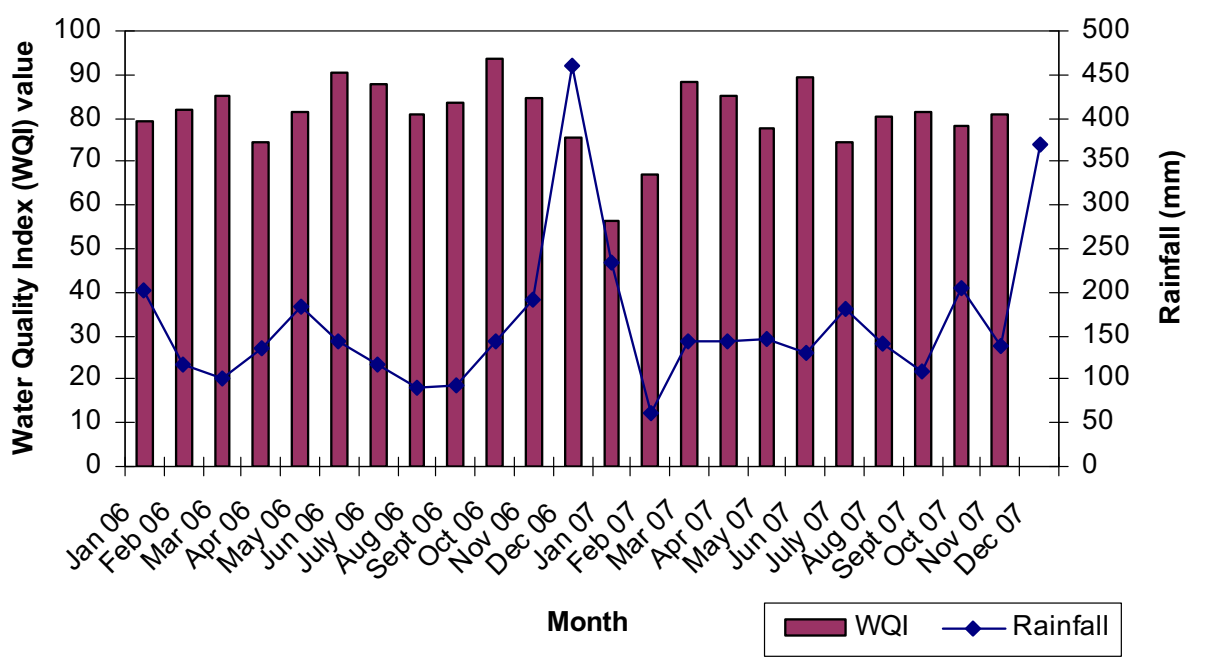

pollutant loads, probably due to the dilution effect of increased water volume in the Muar River.

During the Northeast Monsoon, the total monthly rainfall in November 2006 had increased $34 \%$ compared to October 2006, the WQI dropped to 84.5, within Class II. The total monthly rainfall in December 2006 was over $145 \%$ of the total monthly average of $187.5 \mathrm{~mm}$, while January 2007 received total monthly rainfall more than $70 \%$ of the total monthly average rainfall of $138.2 \mathrm{~mm}$. The Muar River was classified as Class III in December 2006 and January 2007, and December 2006 was the month when the first wave of 2006/07 flood events had occurred, with the WQI of 75.79 and in Slightly Polluted category. However, in January 2007 the WQI had dropped drastically to 56.4 and in Polluted category (Fig. 3; Table 4), which corresponded with the second wave of 2006/07 flood events. Based on the WQI, the water quality class of Muar River for the months of December 2006 and January 2007 required extensive treatment for water supply purposes, being suitable only for very tolerant and most common aquatic species such as the gastropod molluscs, polychaete worms, and hardy fish such as tilapia, and maybe for livestock drinking.

After the big flood events, the lowest mean monthly rainfall of $62.08 \mathrm{~mm}$ in a 2-year period (2006-2007) was recorded in February 2007, i.e., $28 \mathrm{~mm}$ below the monthly average rainfall of the 31-year record. The WQI value of February 2007 was categorized as Slightly Polluted and within Class III. However, about 1 month after the big flood events (in March), the WQI of the Muar River had recovered back to normal, with index range of Clean and classified under Class II. This could be due to the good water circulation, dilution, and mixing, where in March 2007 it had received more than 133 percent of the February 2007 rainfall volume. According to the DOE, the WQI and river water quality of Class II is suitable for potable water monsoon month of October showed comparatively lower 
Table 4 Water quality Class-based classification according to the concentration of $\mathrm{NH}_{3}-\mathrm{N}, \mathrm{BOD}, \mathrm{COD}, \mathrm{DO}, \mathrm{pH}, \mathrm{TSS}$, and the WQI; and Water quality pollution Status-based classification according to the SIAN, SIBOD, SISS, and WQI of the Muar River from January 2006 to November 2007

\begin{tabular}{|c|c|c|c|c|c|c|c|c|c|c|c|c|c|c|}
\hline \multirow[t]{2}{*}{ WQ Parameter /WQI } & \multirow[t]{2}{*}{ Year } & \multicolumn{13}{|c|}{ Water quality class } \\
\hline & & Jan & Feb & Mar & Apr & May & June & July & Aug & Sept & Oct & Nov & Dec & Ave \\
\hline \multirow[t]{2}{*}{$\mathrm{NH}_{3}-\mathrm{N}(\mathrm{mg} / \mathrm{l}) / \mathrm{AN}$} & 2006 & II & II & II & II & II & I & I & II & II & I & I & II & II \\
\hline & 2007 & III & III & I & I & II & I & II & II & II & II & I & N/A & II \\
\hline \multirow[t]{2}{*}{ SIAN } & 2006 & $\mathrm{P}$ & SP & SP & SP & SP & $\mathrm{C}$ & $\mathrm{C}$ & SP & SP & $\mathrm{C}$ & $\mathrm{C}$ & SP & SP \\
\hline & 2007 & $\mathrm{P}$ & SP & SP & $\mathrm{C}$ & SP & $\mathrm{C}$ & SP & SP & SP & SP & $\mathrm{C}$ & N/A & $\mathrm{SP}$ \\
\hline \multirow[t]{2}{*}{ BOD (mg/l) } & 2006 & II & II & II & II & II & II & II & II & II & II & II & II & II \\
\hline & 2007 & II & II & II & II & II & II & II & II & II & II & II & N/A & II \\
\hline \multirow[t]{2}{*}{ SIBOD } & 2006 & $\mathrm{C}$ & $\mathrm{C}$ & $\mathrm{C}$ & $\mathrm{C}$ & $\mathrm{C}$ & $\mathrm{C}$ & $\mathrm{C}$ & $\mathrm{C}$ & $\mathrm{C}$ & $\mathrm{C}$ & $\mathrm{C}$ & $\mathrm{C}$ & $\mathrm{C}$ \\
\hline & 2007 & SP & SP & $\mathrm{C}$ & $\mathrm{C}$ & $\mathrm{C}$ & $\mathrm{C}$ & $\mathrm{C}$ & $\mathrm{C}$ & $\mathrm{C}$ & $\mathrm{C}$ & $\mathrm{C}$ & N/A & $\mathrm{C}$ \\
\hline \multirow[t]{2}{*}{$\mathrm{COD}(\mathrm{mg} / \mathrm{l})$} & 2006 & III & II & III & IV & III & I & II & III & III & I & II & II & III \\
\hline & 2007 & III & III & II & II & II & II & II & II & II & II & II & N/A & II \\
\hline \multirow[t]{2}{*}{ DO (\% saturation) } & 2006 & II & II & II & II & II & II & II & II & II & II & II & II & II \\
\hline & 2007 & II & II & II & II & II & II & II & II & II & II & II & N/A & II \\
\hline \multirow[t]{2}{*}{$\mathrm{pH}$} & 2006 & II & II & I & II & II & II & I & II & II & I & II & II & II \\
\hline & 2007 & IV & II & I & I & II & II & II & II & II & II & III & N/A & II \\
\hline \multirow[t]{2}{*}{ TSS/SS (mg/l) } & 2006 & III & III & I & III & II & I & II & III & II & I & II & III & II \\
\hline & 2007 & III & III & I & III & III & I & III & III & III & III & III & N/A & III \\
\hline \multirow[t]{2}{*}{ SISS } & 2006 & $\mathrm{P}$ & $\mathrm{P}$ & $\mathrm{C}$ & $\mathrm{P}$ & $\mathrm{C}$ & $\mathrm{C}$ & $\mathrm{C}$ & $\mathrm{P}$ & $\mathrm{C}$ & $\mathrm{C}$ & SP & $\mathrm{P}$ & SP \\
\hline & 2007 & $\mathrm{P}$ & $\mathrm{P}$ & $\mathrm{C}$ & $\mathrm{P}$ & $\mathrm{P}$ & $\mathrm{C}$ & $\mathrm{P}$ & $\mathrm{P}$ & $\mathrm{P}$ & $\mathrm{P}$ & SP & N/A & $\mathrm{P}$ \\
\hline \multirow[t]{4}{*}{ Water Quality Index (WQI) } & 2006 & II & II & II & III & II & II & II & II & II & I & II & III & II \\
\hline & 2007 & III & III & II & II & II & II & III & II & II & II & II & N/A & II \\
\hline & 2006 & SP & $\mathrm{C}$ & $\mathrm{C}$ & SP & $\mathrm{C}$ & $\mathrm{C}$ & $\mathrm{C}$ & $\mathrm{C}$ & $\mathrm{C}$ & $\mathrm{C}$ & $\mathrm{C}$ & SP & $\mathrm{C}$ \\
\hline & 2007 & $\mathrm{P}$ & SP & $\mathrm{C}$ & $\mathrm{C}$ & $\mathrm{C}$ & $\mathrm{C}$ & SP & SP & $\mathrm{C}$ & SP & $\mathrm{C}$ & N/A & SP \\
\hline
\end{tabular}

$C$ clean, $S P$ slightly polluted, $P$ polluted, $N / A$ not applicable

supply but conventional treatment is required, the water quality status is suitable for sensitive aquatic species and for recreational use involving body contact.

Form March until June 2007, WQI of the Muar River was classified under Class II with index range of Clean, and the received rainfall ranged from $130.1 \mathrm{~mm}$ in June to $147.4 \mathrm{~mm}$ in April. The WQI of the Muar River was degraded into Class III and categorized as Slightly Polluted in July 2007, with higher rainfall of $180.5 \mathrm{~mm}, 49 \%$ above the monthly average rainfall. The WQI of the Muar River was classified under Class II from August to November 2007, with lower rainfall recorded in September (108.4 mm) and November 2007 (139.1 mm), and these 2 months have WQI range of Clean; but with higher rainfall found in the months of August $(141.39 \mathrm{~mm})$ and October 2007 (205.8 mm), respectively, the WQI for August and October 2007 were classified as Slightly Polluted. The highest average total monthly rainfall in 2007 was recorded in December with $97 \%$ well above the monthly average rainfall of the years from 1980 to 2010. The high rainfall volume had triggering another prolonged flood event in the Muar River Basin from the 2nd to 17th December 2007.

\section{Correlation analysis}

In the period before the flood events and during the first wave of flood events from January 2006 to December 2006, Pearson's $r$ correlation analysis between monthly rainfall and water quality parameters showed that there are highly significant negative relationship between rainfall and DO $(r=-0.784, P<0.01)$, that means if the rainfall volume increases, the DO concentration obtained is lower and vice versa. Thus, high precipitations would lead to deterioration of water quality. However, the results showed that no statistical significance in monthly rainfall with the WQI value and the parameters of $\mathrm{NH}_{3}-\mathrm{N}, \mathrm{BOD}, \mathrm{COD}, \mathrm{pH}$, and SS. There are three significant relationships among water quality parameters calculated, SS had a significant positive relationship with $\mathrm{NH}_{3}-\mathrm{N}(r=0.599, P<0.05)$, and a highly significant negative relationship with $\mathrm{pH}$ ( $r=-0.796, P<0.01)$, and $\mathrm{pH}$ had a significant positive relationship with DO $(r=0.617, P<0.05)$; while BOD and COD was found did not have significant relationships with the other water quality parameters. There are significant correlations between WQI and water quality 
parameters of $\mathrm{NH}_{3}-\mathrm{N}, \mathrm{COD}, \mathrm{pH}$, and $\mathrm{SS}$. The WQI value was positively correlated with $\mathrm{pH}(r=0.722, P<0.01)$, and negatively correlated with $\mathrm{NH}_{3}-\mathrm{N} \quad(r=-0.669$, $P<0.02), \quad$ COD $\quad(r=-0.714, \quad P<0.01), \quad$ and $\quad \mathrm{SS}$ ( $r=-0.912, P<0.01)$ (Table 5).

During the period of second wave flood events and after the flood events from January 2007 to November 2007, there are no significant correlations between the amounts of rainfall with the WQI value and the water quality parameters. There are eight significant relationships among the six physicochemical water quality parameters, the concentration of $\mathrm{NH}_{3}-\mathrm{N}$ was the only variable significantly correlated with all the other five water quality parameters, $\mathrm{NH}_{3}-\mathrm{N}$ had a significant positive relationship with BOD $(r=0.688$, $P<0.02)$, COD $(r=0.870, P<0.01)$, and SS $(r=0.692$, $P<0.02)$, and a significant negative relationship with DO $(r=-0.670, P<0.05)$ and $\mathrm{pH}(r=-0.778, P<0.01)$. A highly significant positive relationship existed between SS and COD $(r=0.791, P<0.01)$, and a significant negative correlation was found between COD and DO $(r=-0.607$, $P<0.05)$, while DO and $\mathrm{pH}(r=0.722, P<0.01)$ revealed a highly significant positive relationship. Except $\mathrm{BOD}$, water quality parameters of $\mathrm{NH}_{3}-\mathrm{N}, \mathrm{COD}, \mathrm{DO}, \mathrm{pH}$, and SS had a highly significant very strong relationship with WQI. Correlation analysis showed that WQI had a positive relationship with DO $(r=0.753, P<0.01)$ and $\mathrm{pH}$ $(r=0.837, P<0.01)$, and a negative relationship with $\mathrm{NH}_{3}-\mathrm{N} \quad(r=-0.908, \quad P<0.01), \quad$ COD $\quad(r=-0.839$, $P<0.01)$, and SS $(r=-0.836, P<0.01)$ (Table 6).

For overall correlation analysis for the period from January 2006 to November 2007, rainfall had a positive relationship with $\mathrm{NH}_{3}-\mathrm{N}, \mathrm{BOD}$, and $\mathrm{SS}$, and had a negative relationship with $\mathrm{COD}, \mathrm{DO}, \mathrm{pH}$, and WQI. Lower strengths of correlations were found between rainfall with the water quality parameters and WQI in the period of second wave flood events and after the flood events in the year 2007 compared to the period before the flood events and during the first wave of flood events in the year 2006. The strength of correlation between rainfall with $\mathrm{NH}_{3}-\mathrm{N}$ and $\mathrm{SS}$ was decreased from strong relationship in year 2006 to no or negligible relationship in year 2007; rainfall and DO correlation strength was decreased from very strong relationship in year 2006 to moderate relationship in year 2007; rainfall and $\mathrm{pH}$ had a strong relationship in year 2006 and 2007 , but the strength of correlation have decreased from high correlation $(r=-0.527)$ in year 2006 to medium correlation $(r=-0.494)$ in year 2007; and there had no or negligible relationship between the amount of rainfall with BOD and COD in year 2006 and 2007; while the correlation between rainfall and WQI had the strength of strong relationship in year 2006 and moderate relationship in year 2007. Except the strength of correlation between WQI and SS found higher in year 2006, the correlations between WQI and the other 5 water quality parameters had higher strengths in year 2007. The strengths of correlations among the water quality parameters were found lower in year 2006, except for the correlation between $\mathrm{pH}$ and SS which was of lower strength of correlation in the year 2007.

\section{Rainfall and water quality parameters}

The water quality results clearly showed that in terms of DO, BOD, COD, $\mathrm{pH}, \mathrm{NH}_{3}-\mathrm{N}$, and TSS, the Muar River water had degraded during the study period, most likely due to the long-term flooding.

\section{Dissolved oxygen $(D O)$}

DO is a measure of the quantity of oxygen gas freely available in water, the level of DO in river is important

Table 5 Pearson correlation coefficient $(r)$ for the rainfall in Muar River Basin, the water quality parameters in the Muar River, and the calculated WQI in the period from January 2006 to December 2006

\begin{tabular}{|c|c|c|c|c|c|c|c|c|}
\hline \multirow[t]{2}{*}{ Parameters } & \multicolumn{8}{|c|}{ Correlation coefficient $(r)$} \\
\hline & $\mathrm{AN} / \mathrm{NH}_{3}-\mathrm{N}$ & BOD & COD & DO & $\mathrm{pH}$ & SS & WQI & Rainfall \\
\hline $\mathrm{AN} / \mathrm{NH}_{3}-\mathrm{N}$ & 1 & & & & & & & \\
\hline BOD & 0.175 & 1 & & & & & & \\
\hline COD & 0.392 & 0.344 & 1 & & & & & \\
\hline DO & -0.132 & -0.157 & 0.151 & 1 & & & & \\
\hline $\mathrm{pH}$ & -0.320 & -0.182 & -0.347 & $0.617^{*}$ & 1 & & & \\
\hline SS & $0.599 *$ & 0.224 & 0.555 & -0.342 & $-0.796 * * *$ & 1 & & \\
\hline WQI & $-0.669 * *$ & -0.419 & $-0.714 * * *$ & 0.364 & $0.722 * * *$ & $-0.912 * * *$ & 1 & \\
\hline Rainfall & 0.464 & 0.032 & -0.144 & $-0.784 * * *$ & -0.527 & 0.428 & -0.412 & 1 \\
\hline
\end{tabular}

* Indicates a significant relationship $(P<0.05)$

** Indicates a significant relationship $(P<0.02)$

*** Indicates a significant relationship $(P<0.01)$ 
Table 6 Pearson correlation coefficient $(r)$ for the rainfall in Muar River Basin, the water quality parameters in the Muar River, and the calculated WQI in the period from January 2007 to November 2007

\begin{tabular}{|c|c|c|c|c|c|c|c|c|}
\hline \multirow[t]{2}{*}{ Parameters } & \multicolumn{8}{|c|}{ Correlation coefficient $(r)$} \\
\hline & $\mathrm{AN} / \mathrm{NH}_{3}-\mathrm{N}$ & BOD & COD & DO & $\mathrm{pH}$ & SS & WQI & Rainfall \\
\hline $\mathrm{AN} / \mathrm{NH}_{3}-\mathrm{N}$ & 1 & & & & & & & \\
\hline BOD & $0.688 * *$ & 1 & & & & & & \\
\hline COD & $0.870 * * *$ & 0.597 & 1 & & & & & \\
\hline DO & $-0.670^{*}$ & -0.396 & $-0.607 *$ & 1 & & & & \\
\hline $\mathrm{pH}$ & $-0.778 * * *$ & -0.525 & -0.581 & $0.722 * * *$ & 1 & & & \\
\hline SS & $0.692 * *$ & 0.364 & $0.791 * * *$ & -0.464 & -0.461 & 1 & & \\
\hline WQI & $-0.908 * * *$ & -0.549 & $-0.839 * * *$ & $0.753 * * *$ & $0.837 * * *$ & $-0.836 * * *$ & 1 & \\
\hline Rainfall & 0.059 & 0.021 & -0.111 & -0.309 & -0.494 & 0.154 & -0.338 & 1 \\
\hline
\end{tabular}

* Indicates a significant relationship $(P<0.05)$

** Indicates a significant relationship $(P<0.02)$

*** Indicates a significant relationship $(P<0.01)$ from an environmental perspective. DO is vital to all forms of aquatic life such as plants, fish, microorganisms, invertebrates, and others. Concentrations of unpolluted fresh water will be close to $10 \mathrm{mg} / \mathrm{l}$. Numerous scientific studies suggest that $4-5 \mathrm{mg} / \mathrm{l}$ of DO is the minimum amount that will support a large, diverse fish population. Typically DO levels less than $2 \mathrm{mg} / \mathrm{l}$ will kill fish.

The DO levels were classified under Class II within the study period from January 2006 to November 2007, the DO concentration ranged from $5.03 \mathrm{mg} / \mathrm{l}$ (January 2007) to $6.54 \mathrm{mg} / \mathrm{l}$ (September 2006) as can be clearly seen in Fig. 4. The DO mean level in the Muar River prior to the big flood events was $5.46 \mathrm{mg} / \mathrm{l}$ in November 2006, but had only dropped slightly to 5.24 and $5.03 \mathrm{mg} / \mathrm{l}$ in December 2006 and January 2007, respectively. The DO levels were lower during the flood events, possibly due to the high pollutant loads such as organics and nutrients that were discharged into the Muar River together with the floodwater, the breakdown of organic material can depress oxygen levels for days or even weeks.

\section{Biochemical oxygen demand $\left(B O D_{5}\right)$ and chemical oxygen demand (COD)}

Other indirect laboratory tests for assessing the DO are the BOD and COD. Bacteria in the water degrade the organic pollution, utilizing DO in the process. The amount of oxygen required to decompose organic matter in a unit volume of water is called the BOD. COD does not differentiate between biologically available and inert organic matter, and it is a measure of the capacity of water to consume oxygen during the decomposition of organic matter and the oxidation of inorganic chemicals such as ammonia and nitrite. The main difference between BOD and COD test is that while BOD determines compounds that can be biologically oxidized, COD measures those substances which can be chemically oxidized. COD values are always greater than BOD values, COD test can be made in a few hours while BOD test is performed over a 5 day period, so it is referred to as a "five day BOD $\left(\mathrm{BOD}_{5}\right)$."

The monthly $\mathrm{BOD}_{5}$ and $\mathrm{COD}$ concentrations in the Muar River for the period from January 2006 to November 2007 are presented in Figs. 5 and 6. The $\mathrm{BOD}_{5}$ of the Muar River water was categorized as Clean and under Class II from January 2006 to November 2007, except during the flood events in January 2007, and the month after the flood events, in February 2007, the BOD $_{5}$ was categorized as Slightly Polluted and under Class II; while the COD was under Class II in November and December 2006 and had then degraded into Class III in January and February 2007 (Table 4).

Urban runoff during the flood events had increased loads of domestic wastes from the streets and sidewalks; nutrients from untreated sewage, discharges from agro-based industries, and manufacturing industries; leaves, grass clippings, and stormwater inputs from residential areas, all of which had increased the oxygen demand in the river. The oxygen utilized for elevated decomposition process of various organic wastes had deprived the aquatic organisms of their vital oxygen supply.

\section{$p H$}

In natural waters, the $\mathrm{pH}$ scale runs from 0 to 14 . The $\mathrm{pH}$ of water should be at 7 which is neutral, $\mathrm{pH}$ values less than 7 indicate acidic water having corrosive properties, and $\mathrm{pH}$ values greater than 7 indicate alkaline properties. Most aquatic lives are sensitive to $\mathrm{pH}$ variations, leading to fish kills and reduction and changes in aquatic communities when the $\mathrm{pH}$ is altered outside their tolerance limits of $\mathrm{pH}$ 5-9.

The $\mathrm{pH}$ values which measure the acidity or alkalinity of the water were the most affected parameter during the flood events, as seen in Fig. 7, where the $\mathrm{pH}$ value recorded was 
Fig. 4 Monthly dissolved oxygen concentrations in the Muar River from the month of January 2006 to November 2007

Fig. 5 Monthly 5-day biochemical oxygen demand concentrations in the Muar River for the year 2006 and 2007

Fig. 6 Monthly chemical oxygen demand concentrations in the Muar River for the year 2006 and 2007

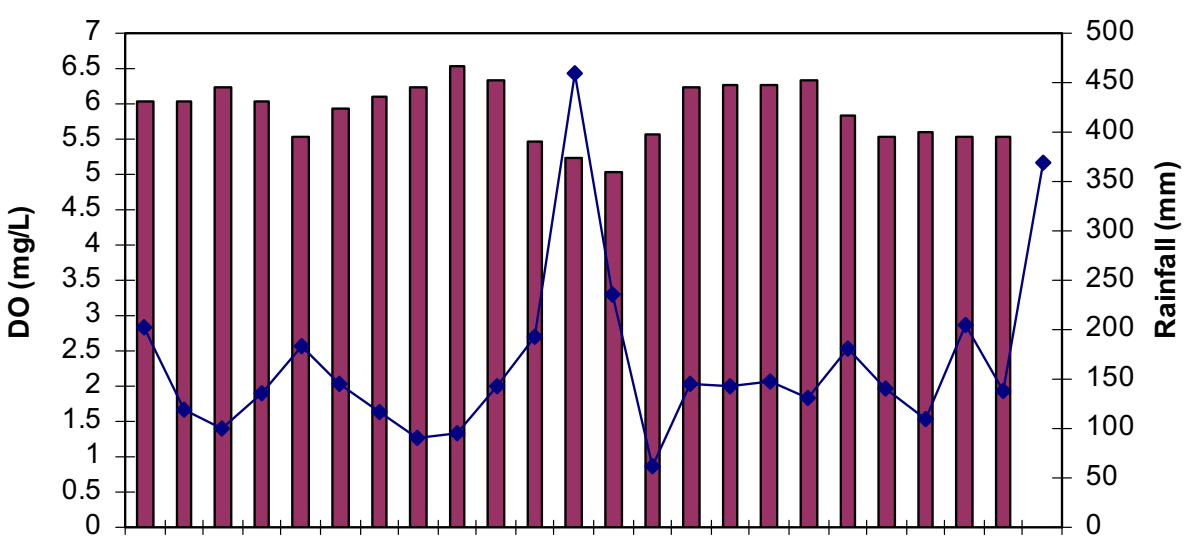

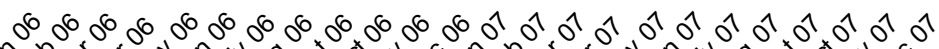

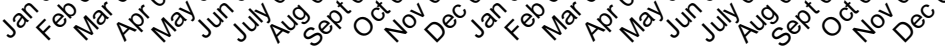

Month
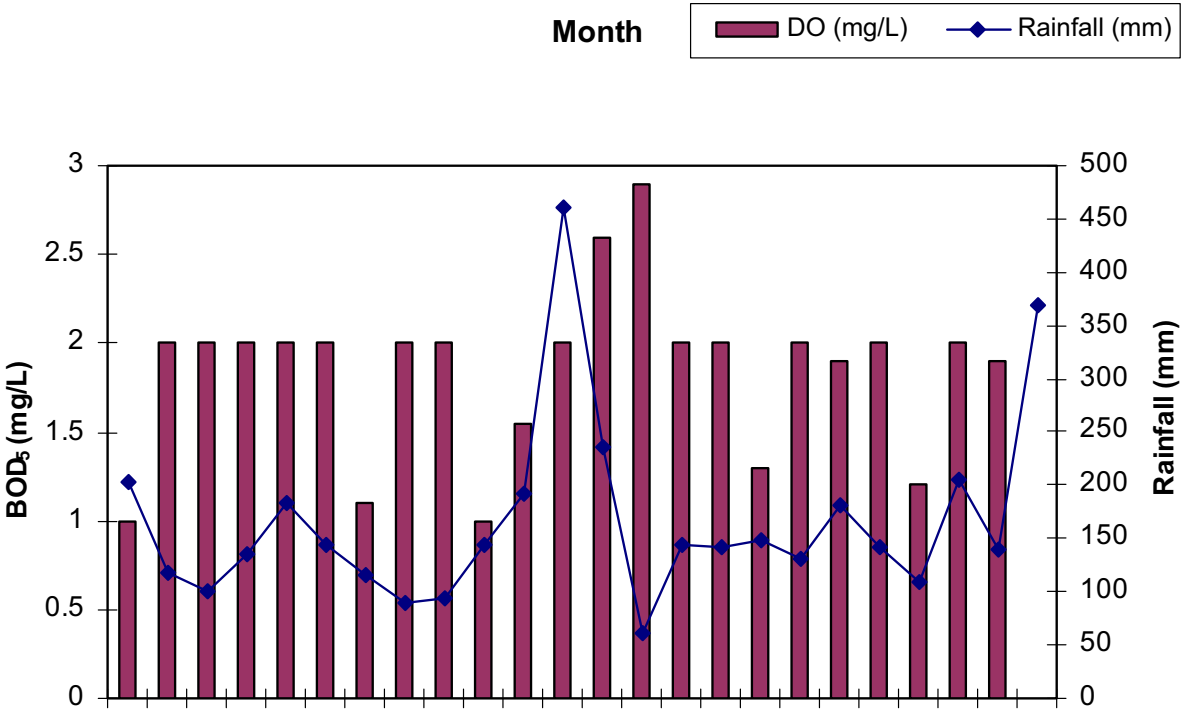

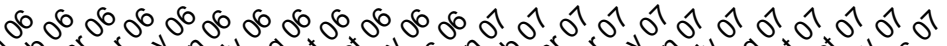

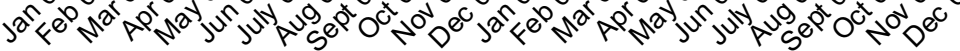

Month $\square$ BOD (mg/L) $\multimap$ Rainfall $(\mathrm{mm})$

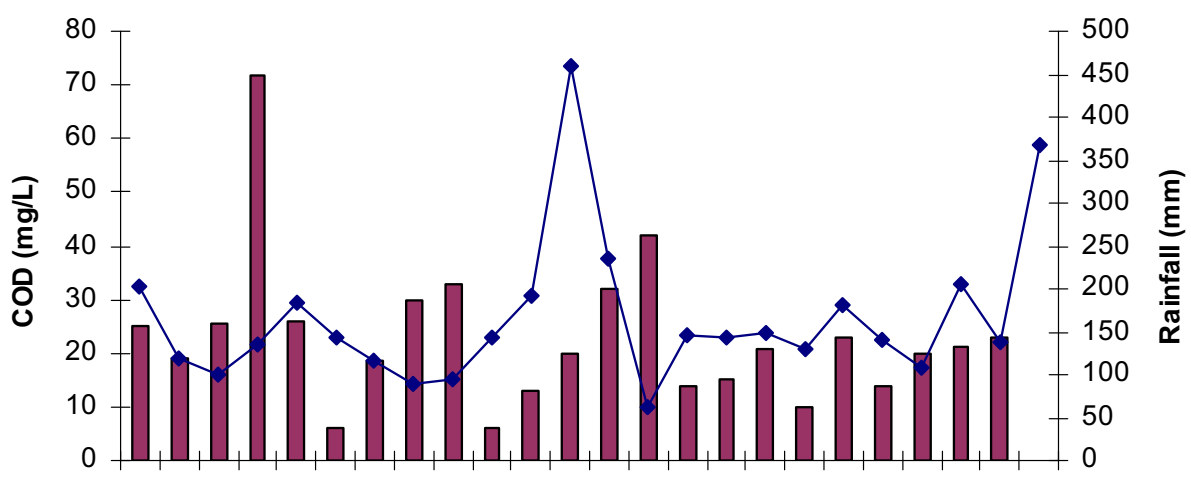

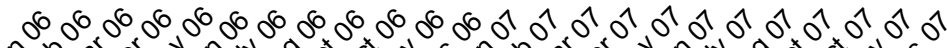

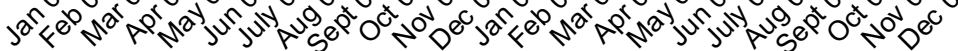

Month

$\square \operatorname{COD}(\mathrm{mg} / \mathrm{L}) \longrightarrow$ Rainfall $(\mathrm{mm})$ 
6.2 and was within Class II in November and December 2006, but had dropped to 3.2 and classified as Class IV during the second wave of flood events in January 2007 (Table 4). The river water during the second wave flooding recorded $\mathrm{pH} 3.2$, which had exceeded the NWQS and not suitable for water supply purposes.

However, after the big flood events, in February 2007, the $\mathrm{pH}$ had increased to normal level of 5.8 and within Class II. Most of the $\mathrm{pH}$ impacts during the flood events were likely caused by excessive runoff with chemicals and pollutants from agriculture practices and irrigating lands, anthropogenic and industrial pollutants, organic wastes, and sewage from the basin area; the heavy rainfall and acid precipitation have caused the leaching of acid and metals concurrently into the water, which can have an immediate or a long-term effect by influencing the chemical composition and $\mathrm{pH}$ fluctuations of the water. The $\mathrm{pH}$ of water affects the solubility of metals and nutritive chemicals, most metals become more water soluble and more toxic when $\mathrm{pH}$ of river decreases, while ammonia becomes more toxic in river with a slight increase in $\mathrm{pH}$.

\section{Ammoniacal-nitrogen $\left(\mathrm{NH}_{3}-\mathrm{N}\right)$}

Before the 2006/2007 flood events, the $\mathrm{NH}_{3}-\mathrm{N}$ levels in the Muar River was classified under Class I with WQI range of Clean in October and November 2006. However, it became classified as Slightly Polluted and within Class II in December 2006 during the first wave of flood events, and had degraded into Class III with WQI range of Polluted and Slightly Polluted in January and February 2007, respectively (Fig. 8; Table 4). Higher concentrations of $\mathrm{NH}_{3}-\mathrm{N}$ found in the Muar River during and after the big flood events could be an indication of heavily loaded with eroded soil and nitrogenous inputs from livestock farming, domestic sewage, industrial waste, and fertilizer runoff. The $\mathrm{NH}_{3}-\mathrm{N}$ form detected in the water is the nitrogen form that is most readily toxic to aquatic life above the tolerable limits. $\mathrm{NH}_{3}-\mathrm{N}$ is formed by chemical and bacterial decomposition of breakdown of the principally proteinbearing materials.

\section{Total suspended solids (TSS)}

TSS is defined as the solid matter in a water sample that can be retained on a glass fiber filter with a pore size less than $2 \mu \mathrm{m}$, typically consisting of fragmental minerals, silt, plankton, sand, nutrients, and metals that have attached to the particles in the water. Figure 9 brings out the concentrations of TSS in the Muar River from January 2006 to November 2007. In November 2006, the TSS was $44 \mathrm{mg} / \mathrm{l}$, classified in Class II with WQI range of Slightly Polluted. The TSS was degraded to Class III with WQI range of Polluted in the months of December 2006, January, and February 2007. TSS recorded was 84.2 and $130 \mathrm{mg} / \mathrm{l}$ in the flooding months of December 2006 and January 2007, respectively. After the big flood events, in February 2007, TSS had increased to $144.6 \mathrm{mg} / \mathrm{l}$. The TSS increase was likely due to the high rainfall and flooding, since particles eroded from the soil surface by the rainfall would be carried in the runoff and deposited as bottom sediments in the river, later to be churned up and re-suspended by further rainfall events.

TSS are materials suspended in the water and high levels of suspended solids in water are capable to settle out onto the streambed, sediment can cover aquatic organisms, eggs, or macro-invertebrate larva in the water bed. This coating can prevent sufficient oxygen transfer and result in the death of buried organisms. High concentrations of suspended solids can lower water quality by increasing the water temperature and water density, reducing the
Fig. 7 Monthly $\mathrm{pH}$ value in the Muar River from the month of January 2006 to November 2007

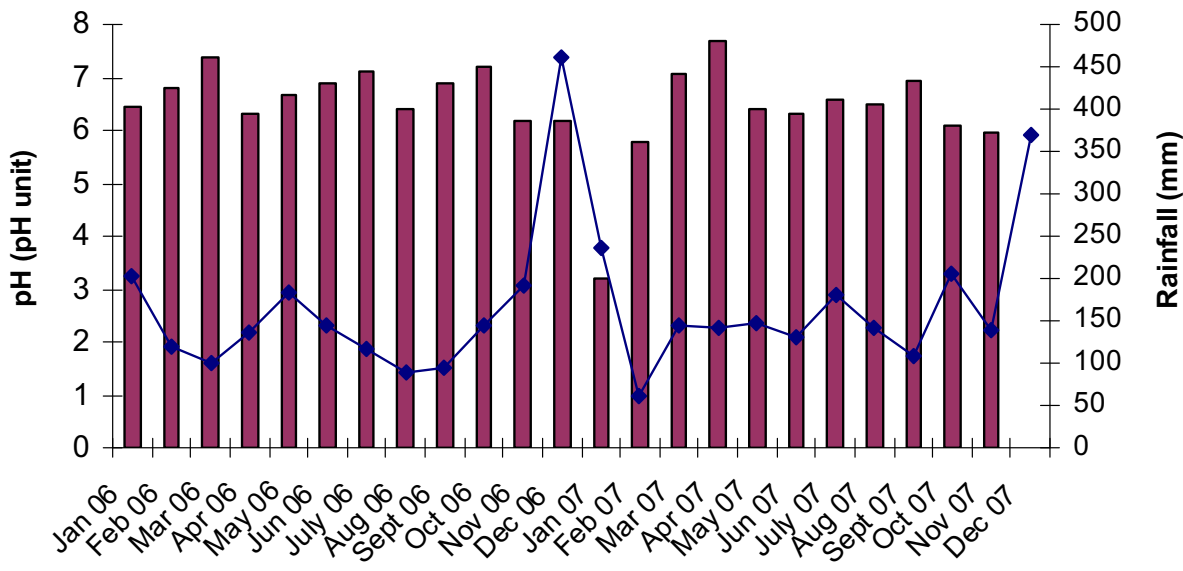

Month 
Fig. 8 Monthly ammoniacalnitrogen $\left(\mathrm{NH}_{3}-\mathrm{N}\right)$ concentrations in the Muar River for the year 2006 and 2007
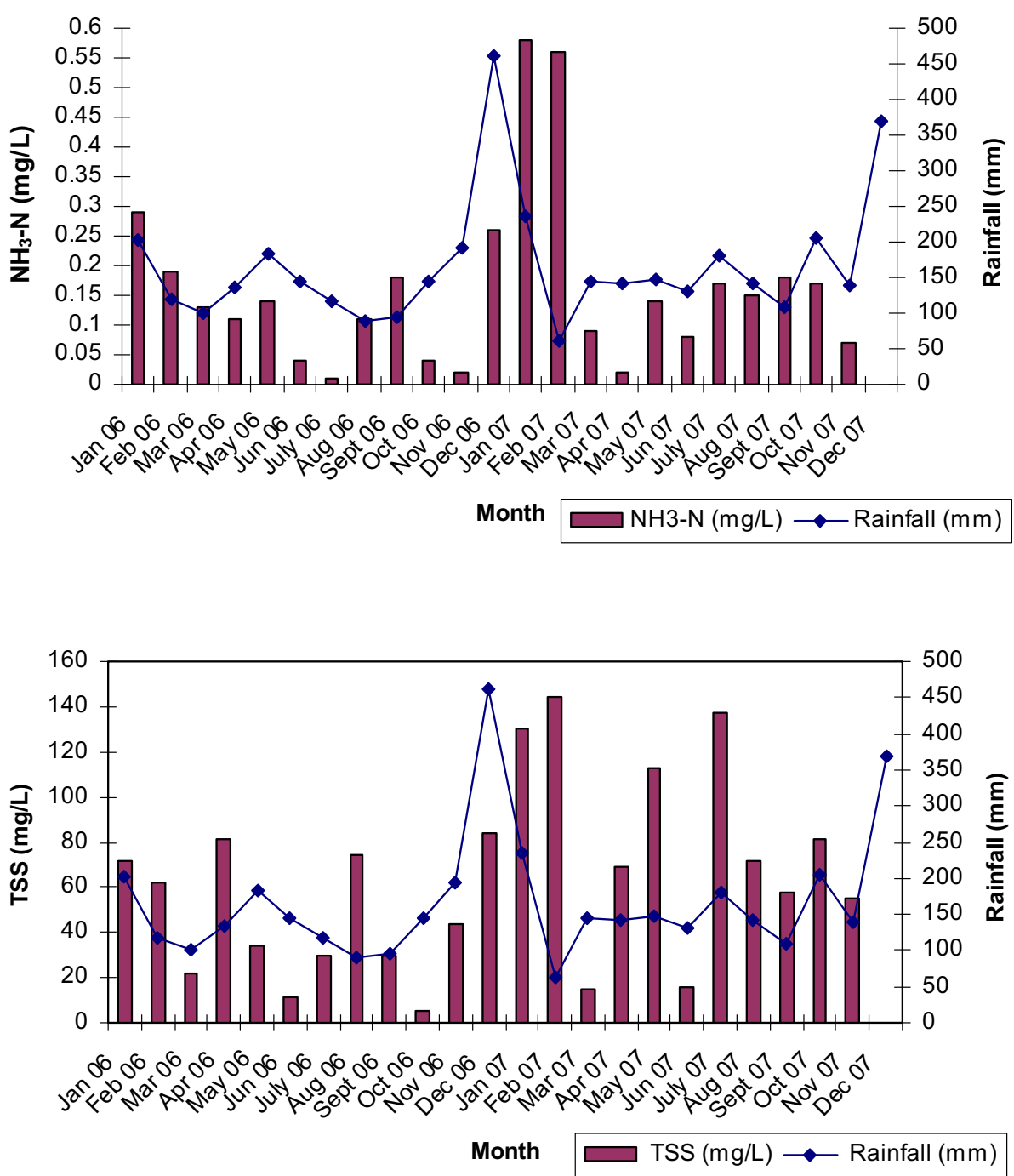

Fig. 9 Monthly total suspended solids concentrations in the Muar River for the year 2006 and 2007 solubility of oxygen gas and water clarity, and affecting osmoregulation of fresh water organisms.

\section{Conclusion}

In this study, the effects of the big flood events of $2006 / 2007$ and the high amounts of rainfall on the river water quality of the Muar River were analyzed based on documented data. The flood events and the amount of rainfall are the key factors affecting the river water quality. Based on the results analysis from this study, DO concentration in Muar River has a general pattern where it is lower during high rainfall period from October to December. The relationship among water quality parameters indicate that high concentration of SS in Muar River caused an increase in the concentration of $\mathrm{NH}_{3}-\mathrm{N}$ and decreased in $\mathrm{pH}$, and the decrease of $\mathrm{pH}$ value had caused lower DO concentration in Muar River. The results of analysis indicate that heavy rainfall and surface runoff had increased the pollutant loads into the Muar River, thus impacting its water quality. The rainfall variability and the flood events that had occurred in the Muar River Basin represented a major challenge in utilizing the Muar River for potable water supply in the area. Watershed characteristics are dependent on the type of surrounding land cover, thus, prescribed activities involving land-use change should be carefully planned and managed since the treatment of polluted water involves substantial cost to the water provider and to the public. It is crucial to ensure that new developments are not approved in flood-prone areas nor allowed to increase the risk of flooding elsewhere.

Acknowledgments We would like to express our sincere thanks and appreciation to the Department of Irrigation and Drainage Malaysia and Johor State, the Malaysian Meteorological Department, the Department of Environment Malaysia, the Department of Survey 
and Mapping Malaysia, the Department of Agriculture Malaysia, respectively, for their support and permission to use the data and information for this study and its publication. This study has been funded by the Malaysian Research University Grants UKM-GUPPLW-08-12-050.

\section{References}

Credit Valley Conservation (2009) Rising to the challenge: a handbook for understanding and protecting the Credit River Watershed, 1st edn. Credit Valley Conservation, Mississauga

Davis AP, McCuen RH (2005) Storm water management for smart growth, 1st edn. Springer Science and Business Media, New York

DID Johor (2007) Flood Report 2006/2007 Johor State. Department of Irrigation and Drainage (DID) Johor State, Malaysia, Ministry of Natural Resources and Environment

DOA Malaysia (2006) Present land use map of Muar River Basin2006, scale 1:150000. Prepared by the Soil Resource Management and Conservation Division, Department of Agriculture, Peninsular Malaysia. Department of Agriculture (DOA) Malaysia, Ministry of Agriculture and Agro-based Industry Malaysia

DOE Malaysia (1985) Development of water quality criteria and standards for Malaysia. Department of Environment Malaysia (DOE) Malaysia, Ministry of Natural Resources and Environment

DOE Malaysia (1994) Classification of Malaysian rivers. Final report on development of water quality criteria and standards for Malaysia (Phase IV-River Classification). Department of Environment (DOE) Malaysia, Ministry of Natural Resources and Environment

Dunnette DA (1979) A geographical variable water quality index used in Oregon. J Water Pollut Control Fed 51:53-61

Inhaber H (1975) An approach to a water quality index for Canada. Water Res 9:821-833

JUPEM (1995) Topographic Map 1:50000 Bahau, Peninsular Malaysia. Edition 1-PPNM. Sheet no. 136. Series DNMM 5101. Published by the Director of National Mapping Malaysia, Department of Survey and Mapping Malaysia (JUPEM), Kuala Lumpur

JUPEM (1995) Topographic Map 1:50000 Segamat, Peninsular Malaysia. Edition 1-PPNM. Sheet no. 146. Series DNMM
5101. Published by the Director of National Mapping Malaysia, Department of Survey and Mapping Malaysia (JUPEM), Kuala Lumpur

JUPEM (1996) Topographic Map 1:50000 Gemencheh, Peninsular Malaysia. Edition 1-PPNM. Sheet no. 145. Series DNMM 5101. Published by the Director of National Mapping Malaysia, Department of Survey and Mapping Malaysia (JUPEM), Kuala Lumpur

JUPEM (1997) Topographic Map 1:50000 Gerisek, Peninsular Malaysia. Edition 1-PPNM. Sheet no. 155. Series DNMM 5101. Published by the Director of National Mapping Malaysia, Department of Survey and Mapping Malaysia (JUPEM), Kuala Lumpur

JUPEM (1997) Topographic Map 1:50000 Kuala Pilah, Peninsular Malaysia. Edition 1-PPNM. Sheet no. 135. Series DNMM 5101. Published by the Director of National Mapping Malaysia, Department of Survey and Mapping Malaysia (JUPEM), Kuala Lumpur

JUPEM (2006) Topographic Map 1:50000 Muar, Peninsular Malaysia. Edition 2-PPNM. Sheet no. 161. Series DNMM 5101. Published by the Director of National Mapping Malaysia, Department of Survey and Mapping Malaysia (JUPEM), Kuala Lumpur

JUPEM (2007) Topographic Map 1:50000 Bakri, Peninsular Malaysia. Edition 2-PPNM. Sheet no. 162. Series DNMM 5101. Published by the Director of National Mapping Malaysia, Department of Survey and Mapping Malaysia (JUPEM), Kuala Lumpur

MMD (2010) General climate of Malaysia. Malaysian Meteorological Department (MMD), Ministry of Science, Technology and Innovation

Sehmi NS (2009) The hydrology of disastrous floods in Asia-an overview. Hydrology and Water Resources Department, World Meteorological Organization, Geneva

Smith DG (1990) A better water quality indexing system for rivers and streams. Water Res 10:1237-1244

UNESCO (2011) The impact of global change on water resources: the response of UNESCO's International Hydrological Programme. International Hydrological Programme, UNESCO/Division of Water Science, Paris

Water Research Foundation (2008) Effects of climate change on public water suppliers. Awwa Research Foundation, Denver 